\title{
Investigating BCL-2 family protein interactions in yeast
}

\author{
Stéphen Manon \\ Institut de Biochimie et de Génétique Cellulaires, UMR 5095, \\ CNRS \& Université de Bordeaux, Campus Careire, CS61390 \\ 1 Rue Camille Saint-Saëns, 33077 Bordeaux, France
}

\begin{abstract}
Among the different models used to study the biochemical properties and function of proteins of the Bcl-2 family, their heterologous expression in the yeast Saccharomyces cerevisiae may look out of place. However, when grown under adequate conditions, yeast cells have mitochondria that have similar properties as those of mammalian cells, and are able to be targeted by mammalian Bcl-2 family members. Yeast thus provides a neutral cellular background to study how proteins of the Bcl-2 family interact with mitochondria, alone or in couple (or more). Most studies done in our laboratory has been done on the pro-apoptotic protein Bax and the anti-apoptotic protein Bcl-xL, but yeast can bring useful information about every protein of the family, in terms of their capacity to interact and to regulate the permeabilization of the outer mitochondrial membrane.
\end{abstract}

\section{Introduction}

Structure/functions studies of Bcl-2 family members, like for any other proteins, can be done in whole cells or in recombinant models. For the later, one difficulty is to obtain proteins under a conformation as close to the native conformation as possible. This may be a mimitation for a protein such as the proapoptotic protein Bax: indeed, Bax exhibits characteristics resembling those of a membrane protein, namely because of the presence of its C-terminal hydrophobic $\alpha$-helix. For long, investigators have produced the protein deprived from this helix (e.g. [1]) or have used detergents to maintain the protein in solution and unaggregated (e.g. [2]). However, those surfactants may have the same membranepermeabilizing effects as active Bax and/or can favor the active conformation of Bax, that maybe a limitation to study its regulation [3].

The heterologous expression of Bcl-2 family members in yeast has been used very early as a middleterm alternative between the expression in mammalian cells and recombinant models. The first direct demonstration that Bax was able to permeabilize mitochondria to cytochrome c has been done in yeast [4], one year before the same demonstration in mammalian cells [5]. Yeast does not have homologs of the Bcl-2 family members, even though a form of programmed cell death is present in yeast ([6] for a review). However, when expressed in yeast, Bcl-2 family members keep their ability to interact with mitochondria and, under adequate conditions, to permeabilize yeast outer miitochondrial membrane to cytochrome c, providing a model to investigate Bax activity ([7] for review).

In this chapter, we describe methods that have been improved for 20 years, that allows to investigate the function of Bax when it is expressed in yeast. These methods have been applied to the study of different Bax mutants [2, 8-12], but can also been applied to the study of combination with other Bcl-2 family members, such as Bcl-xL [12,13], tBid [14], Puma [15], or zebrafish protein Bcl-wav [16]. It can also be used to study the role of other Bax regulation candidates such as Tom22 $[17,18]$ or AKT [11].

\section{Materials}

Prepare all reagents and buffer in ultrapure water $\left(18 \mathrm{M} \Omega . \mathrm{cm}\right.$ at $\left.25^{\circ} \mathrm{C}\right)$. Buffers containing mannitol and sorbitol should be stored at $4^{\circ} \mathrm{C}$. Culture media are autoclaved at $110^{\circ} \mathrm{C}$ for $20 \mathrm{~min}$.

\subsection{Expression system}




\subsubsection{Plasmids}

Because Bcl-2 family members are regulators of life and death, it is necessary to use regulatable expression systems: indeed, the expression of these proteins under the control of constitutively active promoters, may lead to the selection of yeast mutants carrying unwanted alterations (for example, a greater capacity to induce the degradation of these proteins). To prevent this type of bias, cDNA encoding Bcl-2 family members have been cloned under the control of regulatable promoters. The most popular regulatable promoter in yeast is the GAL1/10 promoter, that is controlled by the addition of the fermentable sugar galactose. It is present on commercially available plasmids such as the pYES series (Thermofisher) and the pESC series (Agilent). All these plasmids allow to introduce different tags but this is not recommended for Bcl-2 family members, particularly at the C-terminal end, that is crucial to their function.

The GAL1/10 promoter is activated by galactose and inhibited by glucose. Furthermore, glucose is a strong genetic repressor of the expression of mitochondrial proteins, while galactose has a far more moderate effect, namely on respiratory chain components [19, for review]. Shifting yeast cells from glucose to galactose to induce the expression of a protein controlled by GAL1/10 cause both the expression of the protein of interest and the derepression of mitochondrial proteins. This adds a degree of complexity to the observations, thus possibly being a cause of misinterpretations. The correct practice is to grow yeast cells first on glucose (that we call "preculture"), then on a non-fermentable carbon source (lactate, glycerol, ethanol) to derepress mitochondrial proteins, and finally add a moderate concentration of galactose $(0.5-0.8 \%)$ to induce the expression of the protein of interest. Although less easy to implement, the tet-off system might also been useful, in combination with the GAL1/10 promoter, when the sequential expression of two proteins is studied. Also, contrary to the GAL1/10 promoter, the tet-off system is not sensitive to the carbon source present in the culture medium and can therefore be used on glucose-grown cells (which is useful to study yeast mutants unable to grow on non-fermentable carbon sources) [20]. Plasmids of the pCM series, which allow to express proteins under the control of the tet-off promoter, are available from Euroscarf. The drawback of the tet-off system is that the repression is not total. It is therefore better to use it to express antiapoptotic proteins, that should not impair cell growth.

\subsection{2.cDNA}

Importantly, the yeast codon bias is different from the mammalian one. A striking example is Glycine, which is encoded by the 4 GGN codons. While the GGG codon is evenly used by mammalian cells ( $25 \%$ frequency), it is almost never used by yeast cells (1\% frequency). On the opposite, the GGU codon is the least used by mammalian cells (16\% frequency) while it is the most used by yeast cells (47\% frequency). Replacing GGG codons by GGU codons thus allowed to increase by 5-10 fold the level of expression of human Bax in yeast cells. It is not required to optimize the gene as extensively as we have done for human Bax (Table 2), but optimizing codons that are very rarely used by yeast may be useful. Free tools are now made available by synthetic genes providers to design such optimization.

\subsubsection{Strains}

The $3^{\text {rd }}$ partner is the yeast strain itself. The plasmids described above bear at least one of the following auxotrophic marker: HIS3, LEU2, TRP1 or URA3. Most laboratory yeast strains contain mutations in one or more of these genes, allowing plasmid selection by growing the cells in the absence of the corresponding amino acid or base (histidine, leucine, tryptophan, uracile). Two strains are namely used.

The BY strain series (BY4741, BY4742, BY4743 for the matA haploid, matALPHA haploid and diploid strains, respectively) is the strain in which the Yeast ORF deletion collection, available from Euroscarf, has been built. However, this strain has a poor mitochondrial metabolism, with about two time less 
mitochondrial proteins than the following strain, making it poorly desirable for mitochondria-centered studies.

The W303 strain series (W303-1A, W303-1B, W303 for the matA haploid, matALPHA haploid and diploid strains, respectively) has been widely used by yeast mitochondria investigators around the world since the 1970's. It exhibits a vigorous growth on non-fermentable carbon sources, connected to a high mitochondria content (at least $25 \%$ of the total protein mass when grown on lactate as a carbon source), and bears all 4 auxotrophic markers listed above. The only drawback is that, opposite to the BY strain, there is no centralized collection of mutants, and each laboratory should make its own mutants (or ask to colleagues). However, making a yeast mutant is a relatively easy task, due to the genuinely high ratio of homologous recombination of yeast DNA. We will not detail here the construction of the strains. There are many highest-quality manuals of yeast molecular biology and genetics available, and additionnal informations can be found in the references given in the introduction.

\subsection{Culture Media}

1.YNBglu (100 mL). Dissolve 0.17g Yeast Nitrogen Base (Difco), 0.1g potassium dihydrogenphosphate, $0.5 \mathrm{~g}$ ammonium sulfate, $2 \mathrm{~g}$ glucose, $10 \mathrm{mg}$ of each auxotrophic requirement, in $100 \mathrm{~mL}$ water. Adjust the $\mathrm{pH}$ at 5.5 with $\mathrm{HCl} 2 \mathrm{~N}$.

2.YNBlac (1L). Dissolve 1.7g Yeast Nitrogen Base, $1 \mathrm{~g}$ potassium dihydrogenphosphate, $5 \mathrm{~g}$ ammonium sulfate, 2 g "Drop Mix" (a mixture made with equal weights of 16 aminoacids, except Histidine, Leucine, Lysine, Tryptophan, which are used as selection markers for strains BY and W303), $100 \mathrm{mg}$ of auxotrophic markers, in 200mL water. Add $20 \mathrm{~g}$ of DL-lactic acid, and adjust the volume to $\sim 500 \mathrm{~mL}$. Add 6.5g of $\mathrm{NaOH}$ in pellets. When dissolved, finely adjust the $\mathrm{pH}$ to 5.5 with $\mathrm{HCl} 2 \mathrm{~N}$ or $\mathrm{NaOH} 2 \mathrm{~N}$. Complete the volume at $1 \mathrm{~L}$.

Media can be directly put in Erlenmeyer Flasks plugged with cotton for cultures, or stored in Pyrex storage bottles. Sterilize media at $110^{\circ} \mathrm{C}$ for $20 \mathrm{~min}$. (see note 1).

3.Galactose $(100 \mathrm{~mL})$. Weight $40 \mathrm{~g}$ of galactose and add water up to $100 \mathrm{~mL}$. Sterilize as above in a Pyrex storage bottle. As soon as the sterilization is done, shake the bottle to dissolve any remaining galactose to prevent further crystallisation. If crystals appear, unscrew the cap and heat in a microwave owen for 2 minutes.

\subsection{Buffers for mitochondria preparations}

1.Reducing buffer (250 mL) (see note 2). Pipette 7.3mL of $\beta$-mercaptoethanol in $25 \mathrm{~mL}$ of Tris $1 \mathrm{M}$. Adjust at $250 \mathrm{~mL}$ with water. Measure the $\mathrm{pH}$, that should be $9.1-9.3$ (adjust with $\mathrm{NaOH}$ or $\mathrm{HCl}$, if necessary).

2.KCl/Tris buffer (2L). Weight $75 \mathrm{~g}$ of $\mathrm{KCl}$. Add $20 \mathrm{~mL}$ of Tris $1 \mathrm{M}$. Dissolve in 1L water. Adjust $\mathrm{pH}$ to $\sim 7.0$ with $\mathrm{HCl}$. Adjust the volume at 2L.

3.Digestion Buffer (250mL). Prepare 1L of a stock solution of sorbitol 2M. Mix $170 \mathrm{~mL}$ of this solution with $10 \mathrm{~mL}$ of a $0.25 \mathrm{M}$ solution of citric acid, and $20 \mathrm{~mL}$ of a $0.2 \mathrm{M}$ solution of $\mathrm{Na}_{2} \mathrm{HPO}_{4}$ and $2.5 \mathrm{~mL}$ of a solution of $0.1 \mathrm{M}$ EGTA. Ajust the $\mathrm{pH}$ to 6.5 with $\mathrm{NaOH}$. Adjust the volume at $250 \mathrm{~mL}$ with water. 
4.Spheroplasts washing buffer $(500 \mathrm{~mL})$. Prepare $2 \mathrm{~L}$ of a stock solution of mannitol $0.8 \mathrm{M}$ and $500 \mathrm{~mL}$ of a stock solution of maleic acid $0.5 \mathrm{M}$ adjusted at $\mathrm{pH} 6.8$ with Tris. Mix $250 \mathrm{~mL}$ of the mannitol stock solution with, $187 \mathrm{~mL}$ of the sorbitol stock solution and $5 \mathrm{~mL}$ of Tris/maleate solution. Add $0.5 \mathrm{~g}$ of BSA. Verify the $\mathrm{pH}$, that should be 6.8 (adjust with $\mathrm{NaOH}$ or $\mathrm{HCl}$ if necessary).

5.Homogeneization and Recuperation buffers $(500 \mathrm{~mL}$ each). Mix $750 \mathrm{~mL}$ of the mannitol stock solution, $20 \mathrm{~mL}$ of the Tris/Maleate solution and $20 \mathrm{~mL}$ of EGTA $0.1 \mathrm{M}$. Verify the $\mathrm{pH}$, that should be 6.8 (adjust with $\mathrm{NaOH}$ or $\mathrm{HCl}$ if necessary). Adjust the volume at $1 \mathrm{~L}$. Keep $500 \mathrm{~mL}$ that will be Recuperation Buffer. Dissolve 1g of BSA in the other half, that will be Homegenization buffer.

\subsection{Other solutions}

\subsubsection{Cell proteins extraction}

Protein extraction. Prepare a stock solution of $\mathrm{NaOH} 2 \mathrm{M}$. For each set of experiment, mix $35 \mu \mathrm{L}$ of $\beta$ mercaptoethanol in $965 \mu \mathrm{L}$ of $\mathrm{NaOH} 2 \mathrm{M}$.

Protein precipitation. Prepare a stock solution of TCA 3M (see note 3).

Sample solubilization. Prepare a solution of $2 \%$ SDS in $0.1 \mathrm{M} \mathrm{NaOH}$.

$3 X$ Laemmli buffer $(10 \mathrm{~mL})$. Weight $0.6 \mathrm{~g}$ SDS. Add $1.5 \mathrm{~mL}$ of Tris $1 \mathrm{M}, 0.6 \mathrm{~mL} \beta$-mercaptoethanol, $15 \mathrm{mg}$ of Bromophenol Blue. Complete at $7 \mathrm{~mL}$ with water. Gently mix until all SDS is dissolved. Add $3 \mathrm{~mL}$ of glycerol. Mix again.

\subsubsection{SDS-PAGE}

All solutions should be stored at $4{ }^{\circ} \mathrm{C}$. Prepare the gel solutions in advance so that the polymerization is done at room temperature. We routinely use the Mini-Protean system from Biorad.

Running (for 2gels): $2.7 \mathrm{~mL}$ Acrylamide/bis 37.5/1 40\%; 2mL SDS 0.4\%, Tris/HCl 1.5M pH 8.8, 3.3 $\mathrm{mL}$ water. Add $8 \mu \mathrm{L}$ TEMED and $12 \mu \mathrm{L} 40 \%$ APS just before casting.

Stacking (for 2 gels): $0.4 \mathrm{~mL}$ Acrylamide/bis 37.5/1 40\%; 0.8mL SDS 0.4\%, Tris/HCl 0.5M pH 6.7, 1.8 $\mathrm{mL}$ water. Add $4 \mu \mathrm{L}$ TEMED and $7 \mu \mathrm{L} 40 \%$ APS just before casting.

Pour the Running gel. Check that there is no leak. Gently add a thin layer of water on top. Wait 30 minutes for polymerization. Remove water with Whatman paper. Pour the stacking gel. Put the combs. Wait at least 2 hours before using the gel (overnight is better). Gels can be stored at $4^{\circ} \mathrm{C}$. Pack each gel in wet absorbing paper, and wrap several gels together in plastic food film. If correctly packed, gels can be stored for up to 1 month.

\subsubsection{Transfer and Western-Blots}

Transfer gels on Nitrocellulose membranes using a standard procedure (we use the Mini-Trans Blot system from Biorad).

Saturate membranes in PBST + dry milk 5\%, for 30 minutes at room temperature.

Remove milk.

Put the membrane in an appropriate volume of PBST. Add the primary antibody (see table 3). Incubate overnight at $4^{\circ} \mathrm{C}$.

Remove the primary antibody solution (see note 4).

Rapidly wash the membrane twice with PBST.

Put the membrane in an apropriate volume of PBST. Add the secondary antibody (see table 3).

Uncubate $45 \mathrm{~min}$ at room temperature. 
Remove the secondary antibody solution (see note 5 ).

Wash the membrane at least six times with 10 min incubation.

Reveal the peroxidase activity with a standard ECL method.

\section{Methods}

\subsection{Mitochondria preparation}

1.Pregrow yeast cells by suspending a clone in 3mL YNBglu medium in a $20 \mathrm{~mL}$ glass tube, at $28^{\circ} \mathrm{C}$ under moderate shaking (180rpm). An overnight culture should be sufficient.

2.Transfer $2 \mathrm{~mL}$ of this preculture in $20 \mathrm{~mL}$ of YNBlac medium in a $100 \mathrm{~mL}$ Erlenmeyer flask, at $28^{\circ} \mathrm{C}$ under moderate shaking (180rpm). The remaining $1 \mathrm{~mL}$ can be kept and used for re-inoculating a preculturein YNBglu. Follow the growth of the culture by measuring the O.D. at 550nm. The doubling time of the culture is between 4 to 6 hours. The maximal O.D. should not exceed 6 units.

3.Transfer the $20 \mathrm{~mL}$ culture in $180 \mathrm{~mL}$ of YNBlac medium in a $1 \mathrm{~L}$ flask, and grow as above (see note 4).

4.Dispatch the $200 \mathrm{~mL}$ culture in two 5L-Erlenmeyer flasks containing $1 \mathrm{~L}$ of YNBlac medium. Grow the cell as above until the O.D. of the culture is 0.7 to 0.9 . Add 1:80 volume of the $40 \%$ galactose solution (so that the final concentration of galactose in the culture is $0.5 \%$ ). Grow the cultures under the same conditions as above (see note 6).

5.Bax-expression controlled by the GAL1 promoter reaches a plateau after 8 hours. However, to exacerbate the effects on mitochondria and also for practical reasons, it is useful to prolong the expression up to 14 hours (i.e. overnight).

6.Measure the O.D. of the cultures. $1 \mathrm{~L}$ of culture at 1 O.D. unit corresponds to about $0.5 \mathrm{~g}$ dry weight of cells. Save $0.5 \mathrm{~mL}$ of the culture and kept frozen at $-20^{\circ} \mathrm{C}$ for preparing total extracts. Harvest the rest of the cultures in 1L-centrifugation flasks (4000 x g, $3 \mathrm{~min}$ ). Resuspend the cells in distilled water, reunite the two pellets, complete at $1 \mathrm{~L}$ and centrifuge again (4000 x g, $3 \mathrm{~min})$. Resuspend the cells in distilled water, complete at $200 \mathrm{~mL}$ and centrifuge in a 250mL-flask (4000 x g, $3 \mathrm{~min}$ ).

7.Resuspend the pellet in $10 \mathrm{~mL}$ pre-warmed Reducing Buffer per g dry weight. Incubate at $28^{\circ} \mathrm{C}$ for 15 minutes under gentle agitation (50-100 rpm). (see note 2 ).

During the incubation, weight the adequate amount of zymolyase (10mg per g dry weight) and dissolve it in the adequate volume of pre-warmed digestion buffer (10mL per g dry weight).

8.Centrifuge the cells ( $4000 \mathrm{x} \mathrm{g}, 2 \mathrm{~min}$ ). Resuspend the cells in the $\mathrm{KCl}$ solution (see note 7). Centrifuge (4000 x g, 2 min), resuspend in KCl solution, and centrifuge again (4000 x g, 2 min).

9.Resuspend the pellet in the zymolyase-containing Digestion buffer prepared at step 7. When cells are resuspended, dilute $20 \mu \mathrm{L}$ of the suspension in $1 \mathrm{~mL}$ water and measure the O.D. at 550nm: this is the reference value for intact cells. Incubate the cells at $28^{\circ} \mathrm{C}$ under gentle agitation (50-100rpm). Every 10 minutes, measure the O.D. of the suspension, as above. Because of the digestion of their wall, digested cells swell and splinter when diluted in water, and the O.D. of the suspension decreases. When the O.D. reaches $20 \%$ of the reference value, cells are considered as completely digested. (see note 8). If the experiment has been correctly done, the digestion should be complete after 30-40 minutes. In any case, 
do not prolong the digestion beyond 50 minutes because cells that are already digested - and their content - might be altered.

\section{Important: all subsequent steps should be done on ice or, even better, in a cold room.}

10. Transfer the suspension of digested cells in 30-mL centrifuge tubes (SS34-type). Do not fill the tubes at more than half. Centrifuge (5000 x g, 5 minutes). Gently resuspend the pellet in the Spheroplast Washing Buffer, using the teflon-made pestle of a Potter. The pellet of digested cells should be soft and easy to resuspend. If the pellet is sticky, this means that cells were not correctly digested. Centrifuge, resuspend, centrifuge, resuspend and centrifuge, all in the same conditions as above.

11. Resuspend the cells in an adequate volume of homogenization buffer. Starting from a 2L culture at 2 O.D. unit (2 g dry weight), $20-25 \mathrm{~mL}$ is an adequate volume. Adjust the volume to the initial amount of cells. Pour the suspension in a Waring blender stainleess steel minicontainer (MC1 or MC2, i.e. 37ml or 110mL capacity), and homogeneize with 3 pulses of 3 seconds each.

12.Dilute the suspension at least 4-fold with the homogeneization buffer, and dispatch in 30mLcentrifugation tubes.

13.Centrifuge at low speed (800 x g, $15 \mathrm{~min})$. Transfer carefully the supernatant in fresh tubes, and centrifuge at high speed (17,000 x g, $15 \mathrm{~min})$.

14.Resuspend each mitochondrial pellet in a small volume of the recuperation buffer (1-2mL). Gently homogeneize 3 times in a $5 \mathrm{~mL}$ Potter-Elvehjem homogeneizer equipped with a soft Teflon pestle. Dilute the mitochondrial suspension to 20-25mL with recuperation buffer.

15. Repeat step 13.

16. Resuspend the mitochondrial pellet in the smallest possible volume of recuperation buffer (0.5 1.5mL). Gently homogeneize in the Potter-Elvehjem homogeneizer.

17.Optional: Yeast mitochondria can be frozen without significant alteration of their permeability properties, provided precautions are taken. Place a flat recipient in a flat polystyrene box. The recipient should be as smooth as possible, without asperity. The cut bottom (2-3 cm height) of a standard $2 \mathrm{~kg}$ plastic container of a chemical product is adequate. Pour liquid nitrogen in both the recipient and the polystyrene box (see note 9 ).

18.Pour the mitochondria suspension in a 5mL-syringe equipped with a 26 Gauge needle. Push very gently on the piston so that small droplets of the suspension fall in liquid nitrogen. Move the syringe so that droplets do not "fuse" to each other. Keep your needle far enough from the liquid nitrogen surface so that the suspension does not freeze inside.

19. When all the suspension is frozen as small beads, collect and store them in a cryotube (pre-cooled in liquid nitrogen). Store the cryotubes in a $-80^{\circ} \mathrm{C}$ freezer (see note 10). Frozen mitochondria can be stored for up to 1 year.

20.Thwaving. Prepare a Becher containing hot water. It should be hot, but not boiling: $65-70^{\circ} \mathrm{C}$. Put the adequate amount of mitochondria beads in a standard $5 \mathrm{~mL}$ hemolysis glass-tube (see note 11). Put 
the tube in hot water for several seconds with gentle agitation. As soon as the suspension is thawed, put the tube on ice. (see note 12).

21. Make a protein dosage on the mitochondria suspension. If necessary, dilute the sample to work in the range of the protein dosage).

\subsection{Mitochondrial/Cellular Bax ratio}

The purpose of this experiment is to quantify the amount of Bax in mitochondria compared to the total amount of Bax.

1.Use the sample of cell culture, that has been saved in Point 6 of paragraph 3.1. Based of the O.D. value, calculate the cell concentration ( $1 \mathrm{~mL}$ of culture at 1.O.D. unit contains $2 \times 10^{7}$ cells). Centrifuge a volume equal to $10^{7}$ cells $(10,000 \mathrm{x}$ g, $1 \mathrm{~min})$. Resuspend the pellet in $0.5 \mathrm{~mL}$ water. Add $50 \mu \mathrm{L}$ of a mixture of $\beta$-mercaptoethanol 3.5\% (v/v) in $\mathrm{NaOH} 2 \mathrm{M}$. Vortex. Incubate on ice for $30 \mathrm{~min}$. Add $50 \mu \mathrm{L}$ of TCA 3M. Vortex. Incubate on ice for $15 \mathrm{~min}$. Centrifuge (10,000 x g, $2 \mathrm{~min})$. Carefully remove the supernatant with a pipette. Add $200 \mu \mathrm{L}$ of acetone. Centrifuge (10,000 x g, $2 \mathrm{~min})$. Carefully remove the supernatant with a pipette. Let the pellet dry at room temperature. Add $30 \mu \mathrm{L}$ of a solution of $2 \%$ SDS in $0.1 \mathrm{M} \mathrm{NaOH}$. Solubilize the pellet (use bath sonication if necessary). Add $15 \mu \mathrm{L}$ of Laemmli buffer $3 \mathrm{X}$. Incubate the tubes at $70^{\circ} \mathrm{C}$ for $15 \mathrm{~min}$. Samples are ready for SDS-PAGE.

2. Use a volume of mitochondria suspension (as obtained in 3.1) corresponding to 0.5mg protein. Complete to $100 \mu \mathrm{L}$ with water. Add $10 \mu \mathrm{L}$ of TCA 3M. Vortex. Incubate on ice for $15 \mathrm{~min}$. Centrifuge $(10,000 \mathrm{x}$ g, $2 \mathrm{~min})$.Carefully remove the supernatant with a pipette. Add $75 \mu \mathrm{L}$ of acetone. Centrifuge (10,000 x g, $2 \mathrm{~min})$. Carefully remove the supernatant with a pipette. Let the pellet dry at room temperature. Add $20 \mu \mathrm{L}$ of a solution of $2 \%$ SDS in $0.1 \mathrm{M} \mathrm{NaOH}$. Solubilize the pellet (use bath sonication, if necessary). Add $10 \mu \mathrm{L}$ of Laemmli buffer $3 \mathrm{X}$. Incubate the tubes at $70^{\circ} \mathrm{C}$ for $15 \mathrm{~min}$. Samples are ready for SDS-PAGE.

3.Load cellular and mitochondrial extracts from the same culture on the same SDS-PAGE gel, so that it will be possible to quantify the mitochondrial/cellular ratio. Transfer gels on nitrocellulose membranes, for western-blotting. Use an antibody against Bax and an antibody against a yeast mitochondrial protein, such as porin. After revelation and quantification of the bands, calculate the following ratio for each experimental condition:

(Bax in mitochondria/Porin in mitochondria)/(Bax in cells/Porin in cells)

\subsection{Bax insertion in MOM}

1. For each condition, prepare 4 microfuge tubes containing $0.5 \mathrm{~mL}$ of Recuperation Buffer. Add the following solution to each tube:

Tube 1: $50 \mu \mathrm{L}$ of Recuperation Buffer (control)

Tube 2: $50 \mu \mathrm{L}$ of $\mathrm{Na}_{2} \mathrm{CO}_{3} 1 \mathrm{M}, \mathrm{pH} 10$ (extraction of peripheral proteins)

Tube 3: $50 \mu \mathrm{L}$ of Triton X-100 1\% (extraction of membrane-anchored proteins)

Tube 4: $50 \mu \mathrm{L}$ of Triton X-100 10\% (extraction of membrane-inserted proteins)

2.Adjust the mitochondrial suspension at $10 \mathrm{mg} / \mathrm{mL}$ with recuperation Buffer.

3.Add $50 \mu \mathrm{L}$ of the mitochondrial suspension $(0.5 \mathrm{mg})$ to each tube. Mix gently. Incubate on ice for 15 min. Centrifuge (22,000 x g, $20 \mathrm{~min})$. 
4. Carefully transfer the supernatants in fresh tubes. Add 50 $\mu \mathrm{L}$ of TCA $3 \mathrm{M}$ and proceed for the preparation of samples for electrophoresis like described above (3.2, point 1).

5.Resuspend the pellets in $100 \mu \mathrm{L}$ water. Add $10 \mu \mathrm{L}$ of TCA 3M and proceed for the preparation of samples for electrophoresis like described above (3.2, point 2).

6.Load supernatants and pellets samples on different SDS-PAGE gels (see note 13). After transfer on nitrocellulose, do western-blots against Bax and different mitochondrial proteins (Porin, Cox2, cytochrome $\mathrm{c}, . .$.$) . After quantification, compare the resistance of Bax v/s the different treatments, to$ that of other proteins.

\subsection{Cytochromes quantification}

The spectrophotometric quantification of cytochromes can be done on whole cells or isolated mitochondria. Bax activation leads to the permeabilization of MOM and the release of cytochrome $\mathrm{c}$ in the cytosol. Consequently, isolated mitochondria only contain unreleased cytochrome c. By comparing to mitochondria isolated from control cells, it is possible to measure the ability of Bax to permeabilize MOM.

The release of cytochrome $\mathrm{c}$ is associated to an unstability of the protein, that is more rapidly degraded than the mitochondrial protein. Consequently, yeast cells where cytochrome c is released contain less cytochrome c than control cells. Although this is less precise than measurements on isolated mitochondria, it is less material-consuming and far more rapid, and can be used for a rapid screening of different conditions, before a more precise measurement on isolated mitochondria We will describe both methods.

\subsubsection{Cytochromes quantification on isolated mitochondria}

1.Prepare $2 \mathrm{~mL}$ of a mitochondria suspension at $5 \mathrm{mg} / \mathrm{mL}$ in Recuperation buffer (see note 14).

2.Dispatch the suspension in $1 \mathrm{~mL}$ spectrophotometric cuvettes (see note 15). Load the cuvettes in the Cary 4000 spectrophotometer (see note 16). Make an acquisition between 650 and $500 \mathrm{~nm}$ to check that spectrophotometer settings are adequate: the signal should be more or less horizontal and close to 0 .

3.Add several mg of potassium ferricyanide (oxidant) in the Reference cuvette and several mg of sodium hydrosulfite (reducer) to the Sample cuvette (see note 17). Mix well by inverting the cuvettes several times.

4.Make an acquisition between 650 and 500nm. The spectrum should have the general shape reported in Figure 1, with three peaks around $603 \mathrm{~nm}, 561 \mathrm{~nm}$ and $550 \mathrm{~nm}$, and three wells at 630nm, 575nm and 540nm.

5.Note the O.D. values at those 6 wavelengths. Calculate the differences at $603 \mathrm{~nm}$ minus 630nm $(\alpha)$, $561 \mathrm{~nm}$ minus $575 \mathrm{~nm}(\beta)$, and $550 \mathrm{~nm}$ minus 540nm ( $\gamma)$, corresponding to cytochrome a+a3, b and $c+c 1$, respectively. Also calculate the value $575 \mathrm{~nm}$ minus $540 \mathrm{~nm}(\delta)$, to do a graphical correction of spectrum misshapes.

6.Calculate the concentration of the three cytochromes (in $\mathrm{mM}$ ), including the graphical corrections: Cytochrome a+a3: $\alpha / 24$ 
Cytochrome b: $(\beta+2 \delta / 5) / 18$

Cytochrome $c+c 1:(\gamma-2 \delta / 7) / 18$

7.Convert molar concentrations of cytochromes to pmoles/mg mitochondrial proteins.

8. Since cytochrome b is an unreleased membrane-inserted protein, it is an internal control to the experiments. The ratio cytochrome $c+c 1 /$ cytochrome $b$ is therefore a measurement of Bax ability to release cytochrome c. The maximal ratio may vary from experiment to experiment, depending on mitochondria preparation, but is typically $2.0+/-0.2$. The minimal ratio (if cytochrome c is fully released and only cytochrome c1 remains) is 0.5 (that is the stoechiometry between cytochrome $\mathrm{c} 1$ and cytochrome b within Respiratory Complex III).

Typically, we consider that a ratio above 1.7 corresponds to the absence of release, a value between 1.2 and 1.5 corresponds to a moderate release, and a value below 1.0 corresponds to a strong release.

\subsubsection{Cytochromes quantification on whole cells}

1.Make a cell culture (parapgraph 3.1, points 1-5) in a volume large enough to get $2 \mathrm{~mL}$ of cells at 100 O.D. units (i.e. $100 \mathrm{~mL}$ of culture at 1 O.D. unit, or $50 \mathrm{~mL}$ of culture at 2 O.D. units, or $200 \mathrm{~mL}$ of culture at 0.5 O.D. units, etc...).

2.Centrifuge the cells (5,000 x g, $5 \mathrm{~min})$. Resuspend the pellet in the appropriate amount of water to obtain 50 O.D. units.

3. Dispatch the suspension in the two cuvettes of the spectrophometer. Make an acquisition between 650 and $500 \mathrm{~nm}$ to check that spectrophotometer settings are adequate: the signal should be more or less horizontal and close to 0 , but is expected to be more noisy than the measurements on isolated mitochondrial.

4. Add $2 \mu \mathrm{L}$ of Hydrogen Peroxide (30 \% vol) (oxidant) in the Reference cuvette and several mg of sodium hydrosulfite (reducer) to the Sample cuvette (see note 18). Mix well by inverting the cuvettes several times.

5.Do the acquisition and calculations like on mitochondria suspension (paragraph 3.4.1., points 4-8).

\section{Notes}

1. It is crucial that the temperature of sterilization does not exceed $110^{\circ} \mathrm{C}$ ) (note: sterilized YNB media can be stored for 1-2 weeks without special precuations. However, since some components are lightsensitive, longer periods of storage should be done away from light.

2.The reducing buffer contains a high concentration of $\beta$-mercaptoethanol, that has an unpleasant smell and is toxic. If possible, work under a chemical hood and, in any case, work in a ventilated area.

3. As a very hygroscopic solid acid, pure TCA may cause very severe burns. Always use gloves, lab coat, eyes protection, and weight it with extreme caution. It is less hazardous once in solution, but it should nevertheless by manipulated with caution.

4.It may be worthy to keep primary antibodies solutions for re-use. Antibodies should be added in PBST or TBST without BSA nor milk. For short storages at $4^{\circ} \mathrm{C}$ (one week), it is not necessary to add a 
preservative. For long storage, most antibodies solutions can be frozen and thawed at least once without significant activity loss. Considering their low cost, it is not worth to reuse secondary antibodies.

5.: it is crucial to use transient cultures in Erlenmeyer flasks of intermediate size, and to maintain a 1 to 5 ratio between the volume of culture and the volume of the flask. As a matter of fact, do not inoculate directly a $1 \mathrm{~L}$ culture with a $20 \mathrm{~mL}$ preculture, because the dilution effect will induce a long lag time before yeast cells start to grow again.

6.two liters of culture is the minimal confortable volume to obtain mitochondria of good quality. It is possible to isolate mitochondria from $1 \mathrm{~L}$-cultures but their quality will be poorer.

7.At this stage, the cells should become "sticky" and be more difficult to resuspend. Use a spatula.

8. Alternatively, digestion can be followed under a light microscope at x400 magnification. On a glass plate, mix $2 \mu \mathrm{L}$ of cell suspension and $10 \mu \mathrm{L}$ of water. Digested cells appears swollen, dark-colored, and possibly splintered. I personnally prefer this method. It requires some experience, but is often more precise that the O.D., that may give erroneous measures, particularly when cells are sticken together.

9.Standard safety procedures should apply when manipulating liquid nitrogen, to avoid frostbites.

10.Do not close completely the caps of the cryotubes, until all liquid nitrogen has evaporated.

11.It is crucial to use glass tubes, for better heat conductance.

12.This thawing step is crucial, and requires some experience. Proceed with small amounts of beads, so that the whole preparation is not lost in case of mis-manipulation.

13.The reason for this is that, due to the presence of residual mannitol, supernatant samples often result in "dirty" blots.

14.This is the optimal concentration. However, a reasonable precision can be obtained with suspensions at a concentration above $3 \mathrm{mg} / \mathrm{mL}$.

15.It is better to use black walled cuvettes to limit diffusion

16.The crucial factor is to have a spectrophotometer able to depict a small signal from a high basal level due to light diffusion. This is why a true dual monochromator equipped spectrophotometer, such as the Varian Cary 4000, is required.

17.The precise amount may depend of the degree of purity, but $5 \mathrm{mg}$ is a good starting point. Do not prepare solutions of these products, because they tend to be rapidly degraded in solution.

18.Potassium ferricyanide cannot be used on whole cells because it is not permeant.

\section{Bibliography}


1. Czabotar PE, Westphal D, Dewson G, Ma S, Hockings C, Fairlie WD, Lee EF, Yao S, Robin AY, Smith BJ, Huang DC, Kluck RM, Adams JM, Colman PM (2013) Bax crystal structures reveal how BH3 domains activate Bax and nucleate its oligomerization to induce apoptosis. Cell 152:519-531

2. Simonyan L, Légiot A, Lascu I, Durand G, Giraud MF, Gonzalez C, Manon S. (2017) The substitution of Proline 168 favors Bax oligomerization and stimulates its interaction with LUVs and mitochondria. Biochim Biophys Acta 1859:1144-1155

3.Antonsson B, Montessuit S, Lauper S, Eskes R, Martinou JC (2000) Bax oligomerization is required for channel-forming activity in liposomes and to trigger cytochrome c release from mitochondria. Biochem J 345:271-278.

4.Manon S, Chaudhuri B, Guérin M (1997) Release of cytochrome c and decrease of cytochrome c oxidase in Bax-expressing yeast cells, and prevention of these effects by coexpression of BclxL. FEBS Lett 415:29-32

5.Jürgensmeier JM, Xie Z, Deveraux Q, Ellerby L, Bredesen D, Reed JC (1998) Bax directly induces release of cytochrome c from isolated mitochondria. Proc Natl Acad Sci U S A 95:4997-5002.

6.Carmona-Gutierrez D, Eisenberg T, Büttner S, Meisinger C, Kroemer G, Madeo F (2010) Apoptosis in yeast: triggers, pathways, subroutines. Cell Death Differ 17:763-773.

7.Renault TT, Dejean LM, Manon S (2017) A brewing understanding of the regulation of Bax function by Bcl-xL and Bcl-2. Mech Ageing Dev 161:201-210

8.Priault M, Cartron PF, Camougrand N, Antonsson B, Vallette FM, Manon S (2003) Investigation of the role of the C-terminus of Bax and of tc-Bid on Bax interaction with yeast mitochondria. Cell Death Differ 10:1068-77.

9. Arokium H, Camougrand N, Vallette FM, Manon S (2004) Studies of the interaction of substituted mutants of BAX with yeast mitochondria reveal that the C-terminal hydrophobic alpha-helix is a second ART sequence and plays a role in the interaction with anti-apoptotic BCL-XL. J Biol Chem 279:52566-52573.

10. Arokium H, Ouerfelli H, Velours G, Camougrand N, Vallette FM, Manon S (2007) Substitutions of potentially phosphorylatable serine residues of Bax reveal how they may regulate its interaction with mitochondria. J Biol Chem 282:35104-35112.

11.Simonyan L, Renault TT, Novais MJ, Sousa MJ, Côrte-Real M, Camougrand N, Gonzalez C, Manon S (2016) Regulation of Bax/mitochondria interaction by AKT. FEBS Lett 590:13-21

12.Garenne D, Renault TT, Manon S (2016) Bax mitochondrial relocation is linked to its phosphorylation and its interaction with Bcl-xL. Microb Cell 3:597-605

13.Renault TT, Teijido O, Missire F, Ganesan YT, Velours G, Arokium H, Beaumatin F, Llanos R, Athané A, Camougrand N, Priault M, Antonsson B, Dejean LM, Manon S (2015) Bcl-xL stimulates Bax relocation to mitochondria and primes cells to ABT-737. Int J Biochem Cell Biol 64:136-146.

14.Gonzalvez F, Bessoule JJ, Rocchiccioli F, Manon S, Petit PX (2005) Role of cardiolipin on tBid and tBid/Bax synergistic effects on yeast mitochondria. Cell Death Differ 12:659-667.

15.Gallenne T, Gautier F, Oliver L, Hervouet E, Noël B, Hickman JA, Geneste O, Cartron PF, Vallette FM, Manon S, Juin P (2009) Bax activation by the BH3-only protein Puma promotes cell dependence on antiapoptotic Bcl-2 family members. J Cell Biol 185:279-90.

16.Prudent J, Popgeorgiev N, Bonneau B, Thibaut J, Gadet R, Lopez J, Gonzalo P, Rimokh R, Manon S, Houart C, Herbomel P, Aouacheria A, Gillet G (2013) Bcl-wav and the mitochondrial calcium uniporter drive gastrula morphogenesis in zebrafish. Nat Commun 4:2330

17. Bellot G, Cartron PF, Er E, Oliver L, Juin P, Armstrong LC, Bornstein P, Mihara K, Manon S, Vallette FM (2007) TOM22, a core component of the mitochondria outer membrane protein translocation pore, is a mitochondrial receptor for the proapoptotic protein Bax. Cell Death Differ 14:785-794 
18.Renault TT, Grandier-Vazeille X, Arokium H, Velours G, Camougrand N, Priault M, Teijido O, Dejean LM, Manon S (2012) The cytosolic domain of human Tom22 modulates human Bax mitochondrial translocation and conformation in yeast. FEBS Lett 586:116-121

19.Gancedo JM (1998) Yeast Carbon Catabolite Repression. Microbiol Mol Biol Rev 62:334-361 20.Garí E, Piedrafita L, Aldea M, Herrero E (1997) A Set of Vectors with a Tetracycline-Regulatable Promoter System for Modulated Gene Expression in Saccharomyces cerevisiae. Yeast 13:837-848 


\begin{tabular}{|l|l|l|l|}
\hline Plasmid & Promoter & Selection marker & Provider \\
\hline pYES2/CT & GAL1 & URA3 & Thermofisher \\
\hline pYES3/CT & GAL1 & TRP1 & Thermofisher \\
\hline pYES6/CT & GAL1 & bsd (blasticidin resistance) & Thermofisher \\
\hline pESC-HIS & GAL1/10* & HIS3 & Agilent \\
\hline pESC-LEU & GAL1/10* & LEU2 & Agilent \\
\hline pESC-TRP & GAL1/10* & TRP1 & Agilent \\
\hline pESC-URA & GAL1/10* & URA3 & Agilent \\
\hline pCM184 & tet-off $\left(\right.$ tetO $\left._{7} / C Y C 1\right)$ & TRP1 & Euroscarf \\
\hline pCM189 & tet-off $\left(\right.$ tetO $_{7} /$ CYC1) & URA3 & Euroscarf \\
\hline
\end{tabular}

Table 1: Plasmids that have sucessfully been used to express Bcl-2 family members in yeast. *Both GAL1 and GAL10 promoters are present in opposite directions, with two distinct multicloning sites. 


\begin{abstract}
Native
ATG GAC GGG TCC GGG GAg CAG CCC AGA GGC GGG GGG CCC ACC AGC TCT GAG CAG ATC ATG AAg ACA GGG GCC CTT TTG CTT CAG GGT TTC ATC CAG GAT CGA GCA GGG CGA ATG GGG GGG GAG GCA CCC GAG CTG GCC CTG GAC CCG GTG CCT CAG GAT GCG TCC ACC AAG AAG CTG AGC GAG TGT CTC AAG CGC ATC GGG GAC GAA CTG GAC AGT AAC ATG GAG CTG CAG AGG ATG ATT GCC GCC GTG GAC ACA GAC TCC CCC CGA GAG GTC TTT TTC CGA GTG GCA GCT GAC ATG TTT TCT GAC GGC AAC TTC AAC TGG GGC CGG GTT GTC GCC CTT TTC TAC TTT GCC AGC AAA CTG GTG CTC AAG GCC CTG TGC ACC AAG GTG CCG GAA CTG ATC AGA ACC ATC ATG GGC TGG ACA TTG GAC TTC CTC CGG GAG CGG CTG TTG GGC TGG ATC CAA GAC CAG GGT GGT TGG GAC GGC CTC CTC TCC TAC TTT GGG ACG CCC ACG TGG CAG ACC GTG ACC ATC TTT GTG GCG GGA GTG CTC ACC GCC TCA CTC ACC ATC TGG AAG AAG ATG GGC TGA

\section{Optimized for yeast expression}

ATG GAC GGT TCC GGT GAA CAA CCA AGA GGT GGG GGT CCA ACC TCC TCT GAA CAA ATC ATG AAG ACT GGT GCC TTG TTG CTT CAA GGT TTC ATC CAA GAC AGA GCT GGT AGA ATG GGT GGT GAA GCT CCA GAA TTG GCC TTG GAC CCA GTT CCA CAA GAC GCT TCC ACC AAG AAG TTG TCT GAA TGT TTG AAG AGA ATC GGT GAC GAA TTG GAC TCT AAC ATG GAA TTG CAA AGA ATG ATT GCC GCT GTC GAC ACC GAC TCC CCA AGA GAA GTC TTC TTC AGA GTC GCC GCT GAC ATG TTC TCT GAC GGT AAC TTC AAC TGG GGT AGA GTT GTC GCC TTG TTC TAC TTC GCC TCT AAG TTG GTC TTG AAG GCC TTG TGT ACC AAG GTC CCA GAA TTG ATC AGA ACC ATC ATG GGT TGG ACT TTG GAC TTC TTG AGA GAA AGA TTG TTG GGT TGG ATC CAA GAC CAA GGT GGT TGG GAC GGT TTG TTG TCC TAC TTC GGT ACT CCA ACT TGG CAA ACC GTT ACC ATC TTC GTT GCC GGT GTC TTG ACC GCC TCT TTG ACC ATC TGG AAG AAG ATG GGT TGA
\end{abstract}

Table 2: cDNA sequences of native human Bax (top) and substitutions (in bold) made to obtain the yeast-optimized cDNA (bottom). 


\begin{tabular}{|l|l|l|l|}
\hline Antigen & Antibody/Company & Host & Dilution \\
\hline Human Bax & N20 / Santa-Cruz & Rabbit & $1 / 5,000$ \\
\hline Human Bax & 2D2 /Santa-Cruz & Mouse & $1 / 2,000$ \\
\hline Human Bcl-xL & E18 /Abcam & Rabbit & $1 / 10,000$ \\
\hline Yeast Porin & 16G9E6BC4 /Thermofisher & Mouse & $1 / 50,000$ \\
\hline Yeast Phosphoglycerate kinase & 22C5D8 /Thermofisher & Mouse & $1 / 10,000$ \\
\hline Yeast Cytochrome c & $\begin{array}{l}\text { Custom antibody raised against } \\
\text { purified yeast cytochrome c from } \\
\text { Sigma-Aldrich (C-2436) }\end{array}$ & Rabbit & $1 / 5,000$ \\
\hline Mouse IgG & Peroxidase-Coupled/ Jackson & Goat & $1 / 10,000$ \\
\hline Rabbit IgG & Peroxidase-Coupled/ Jackson & Goat & $1 / 10,000$ \\
\hline
\end{tabular}

Table 3: List of antibodies that have been routinely used for studying Bax and Bcl-xL expression in yeast, and adequate controls. 